\title{
ע FACILITATING POLITICAL STABILITY: COHABITATION OF NON-LEGALISTIC ISLAM AND THE MOROCCAN MONARCHY
}

\author{
Žilvinas Švedkauskas \\ Eberhard-Karls University of Tübingen
}

\begin{abstract}
Focusing on the role of non-legalistic Islam (Sufism and popular Islam), this paper aims to provide an explanation for the distinctness of Morocco defined by increasing political stability and decreasing group grievances, contrasting with the situation in other countries of North Africa. Based on fieldwork carried out in March 2015, this study employs segmentary theory and the "Governance of Religion" approach in constructing an analytical model explaining cohabitation between the Moroccan monarchy and actors of non-legalistic Islam. Results of the research reveal that 1) actors of non-legalistic Islam in Morocco, though representing a variety of organizational structures and political orientations, can be divided into two groups: traditional vs. reformed non-legalistic Islam. 2) This religious distinction is important politically. For example, actors of traditional non-legalistic Islam can provide social services in the Moroccan periphery or create a background for regional "religious diplomacy". However, they are not able or willing to include members of the wider society. In contrast, actors within reformed non-legalistic Islam aim to mobilize new followers for political causes. 3) Consequently, the Moroccan monarchy seems to apply various governance tools in regulating or co-regulating these actors; these tools include, among other things, direct funding, the co-optation of leaders, and sanctions. Analysis shows that actors representing non-legalistic Islam are engaged in the social life of the country and that this engagement results in cohabitation with the Moroccan monarchy. As this paper argues, this cohabitation facilitates political stability and prevents an increase of group grievances.
\end{abstract}

\section{INTRODUCTION}

The person who has no sheik (and it is the spiritual leader of any sect), the devil will be his guide, so you always need someone in life to guide you, someone wise, someone who really tries to detach you completely from any violent concept, to teach you discipline. (An elderly male director of a local NGO, Berkane, 20 Mar. 2015)

The processes that started in the Middle East and North Africa in 2011, also known as the "Arab Spring", were the reason behind the end of some of the authoritarian regimes in the region. ${ }^{1}$

1 The author of this paper would like to thank Prof. Egdūnas Račius (Vytautas Magnus University, Kaunas) and two anonymous reviewers for constructive comments and ideas that helped to improve earlier versions of this manuscript. 
Despite these changes, stable political regimes in most of these countries. On the contrary, today we hear more and more about the "Arab Winter", a large-scale instability following revolutions and coup d'états. Given this trend, it seems important to research the preconditions for regime survival and political stability associated with it.

In this regard, the case of Morocco is particularly interesting. The kingdom is the most stable country in the region and performs comparably well according to indexes such as the Fragile State Index, published by "The Fund for Peace" institute. This Moroccan distinctness is somewhat puzzling. Although other countries in the region witnessed an increase of group grievances within their societies, which is an especially essential factor in predicting unrest in North Africa and the Middle East (Pargeter 2009: 1031-1044), in Morocco during the last five years, this indicator has remained unchanged or has even fractionally decreased. ${ }^{2}$ A question therefore arises: what are the reasons behind what may be described as pax maroccana?

Until today, scientists employing an anthropological approach have mostly researched countries that have (re-)established their independence after decolonisation. The case of Moroccan society and questions related to its political stability are no different. We should first mention studies carried out in the second half of the twentieth century by Clifford Geertz (1971), Elaine Combs-Schilling (1989), Ernest Gellner (1969), and Henry Munson (1993). Most prominent French scholars employ a more historical approach; examples include Charles-André Julien $(1978 ; 1982)$ and Jacques Berque (1982). A common feature in their works is the analysis of the junctions of religious and political institutions in Morocco. These scholars base their ideas on the experience and self-identification of local communities, where religion in general, and Islam, in particular, plays a very important role, affecting the social arrangement of the whole country. The segmentary theory formulated by Gellner (1992) to explain dynamics within Moroccan society can be identified as a prototype of this type of literature.

A second, more recent and nuanced body of research is connected with postcolonial and literary theories and discourse analysis, reflecting the work of the above-mentioned anthropologists. A good example of it is the "State in Society" approach (Migdal 2004). Authors such as political scientist Joel S. Migdal analyse ways in which new states in postcolonial world use local metaphors, create new ideologies and new forms of normative solidarity, and try to prevent inner grievance and instability (Zorin 2001: 57-73).

A third group of scientists argue that the Moroccan context, and the relationship between religion and politics therein, are particularly suitable for a strategic reinvention of history (Ghoulaichi 2005). It is important while creating alliances between the monarchy and different Islamic groups, adjusting them to the changing needs of different times. The result is regime stability. These ideas largely correspond to arguments of the "Governance of Religion" approach, recently introduced in studies of Muslim societies by IMISCOE (International Migration, Integration, and Social Cohesion) network scholars Marcel Mausen and Veit Bader. Drawing largely on the framework already used for studying complex cases in other disciplines (for example, public administration), this approach enables a researcher to identify different directions and forms of interaction between the state and various religious groups.

\footnotetext{
2 Examining the Fragile State Index, we can notice that today the risk for Morocco of becoming politically unstable is one of the lowest in North Africa. What is more, during the last five years, scores of Morocco have been steadily decreasing, whereas other countries in the region have witnessed a rise in political instability, or their scores remained relatively high; see $<$ fsi.fundforpeace.org $>$.
} 
The research presented by this article was carried out in the "grounded" manner described by Strauss and Glaser (Strauss \& Corbin 1994: 273-285). Theories used for the analysis of gathered data were employed, tested, and rejected or accepted during the process of fieldwork in Northern Morocco, in Fez, Sefrou, Berkane, and Madagh (March 2015). Hence, fieldwork and the development of a theory were two parts of the same process. This approach was chosen over the testing of a particular theory, since the ideas and interpretations of local informants were given a central role.

In total, 35 Moroccans participated in the study. Both before and throughout the fieldwork, certain types of key informants, representing specific groups of special interest to this research, were identified and targeted (Bryman 2008: 409). Members of religious organizations, local academia, community leaders, public servants, and NGO representatives were given priority, because of the high likelihood that they would retain substantial knowledge about the make-up of the national and local politico-religious field, the main actors represented in it, and its history, evolution and inner interactions.

Fieldwork included individual face-to-face interviews, group discussions, carried out in Moroccan Arabic, French and English, and extensive participant observation. In the process, postcolonial and literary theories, and the "State in Society" approach, focused on discourse analysis and the role of elites, were put aside. Instead, taking into account the type of information gathered, the "Governance of Religion" approach, debating and reviewing ideas of segmentary theory as proposed by Ernest Gellner, was chosen.

The goal of this article is to present the findings of the fieldwork and provide an analytical model for understanding complex, overlaying religious and political structures in Morocco, based on the "Governance of Religion" approach. In this regard, this article reflects the ideas of French social theorist Pierre Bourdieu and his "field" theory, focusing on how relatively autonomous arenas coalesce around some specific social activities - including politics, religion, intellectual thinking, and the judiciary - and how they come to be governed by specific rules. ${ }^{3}$ In a similar manner to Bourdieu, who aimed to show that ideologies and ideas proper to various actors, whose actions structure the "field", are a function of their position towards each other, this article also attempts to describe how the positioning of particular actors in the Moroccan politico-religious "field" affects their further interactions and power relations, relevant for the facilitation of political stability in the country.

Taking into account today's unrest in the Muslim world, this paper is valuable as a means to better understand the logic behind the interaction of Islam and politics. Moreover, it aims to improve existing academic theories, synthesize recent case studies (prevailing in the field), and present a more thorough picture of the fragmented religious landscape in Morocco.

\section{Various Islams}

Even though processes of globalization are frequently mentioned as the defining social force of the modern or postmodern world, many authors argue that, for Muslims, Islam still dominates the public sphere, subordinating politics, the economy, and so on. ${ }^{4}$ For example, Ernest Gellner (1992) claims that the dominance of Islam is especially evident at least within Muslim populations in the Middle East and North Africa.

3 For further discussion, see Swartz 1997.

4 For an overview of the debate on religion, state, and society dynamics in Muslim countries, see Hassan 2015. 
Notwithstanding inner fluidity, contradictions, and multiple roles of individual religious actors, a considerable number of scholars agree that we can talk - in generalizations, of course - about three main patterns of Islam: legalistic Islam, non-legalistic Islam, and contemporary Islamic revivalism. The classification presented here is borrowed from the works of Egdūnas Račius, a Lithuanian scholar of Islamic studies (Račius 2013: 18-22). Račius's simple presentation is useful in this study because it enables a quick and informative transition towards a more in-depth analysis of Moroccan non-legalistic Islam. A threefold classification includes the following:

1. Legalistic Islam, associated with a normative theory of Islamic law and fikh, and its "practice", regulated by the four biggest schools: Hanafi, Maliki, Shafi'i, Hanbali (Sunni), and smaller schools of other Islamic sects (Shiite and Khawarij). Encompassing a wide range of juristic traditions and more recent reformist initiatives, starting around the end of nineteenth century, legalistic Islam can currently be broadly understood as a "legal system" reminiscent of bureaucratic western structures, seeking to ensure the application of Islamic law to constantly changing social realities (Calder 2016). Ulama 'Islamic scholars' are the most important actors in this pattern.

2. Non-legalistic Islam can often be defined by its nonconformity with the normative Islamic tradition. Even though there exists no consensus on the boundaries of the following terms, we discuss below this second Islamic pattern as being composed of two major elements: 1) syncretic popular Islam (Eickelman 2016), attracting rural, sometimes illiterate populations, often adhering to a cult of local saints, and defined by visitations of mausoleums and the religious festivals organized around them; ${ }^{5}$ and 2) Sufism as practiced by hierarchical Sufi turuq 'brotherhoods, organizations' (singular tariqa), ranging from simple "short-lived preservations for devotional exercises to vast interregional organizations with a high degree of institutional coherence" (Chittick 2016). Members of these organizations traditionally exercise group prayers, preach for peace and tolerance, and follow a charismatic leader or a sheik. Most of the time, a sheik is also sharif, which means that he is considered as a descendent of the Prophet Muhammad.

3. Contemporary Islamic revivalism includes a wide spectrum of modern Islamic movements and governments aiming to (re-)Islamize Muslim societies or appealing to religion to mobilize popular support (Esposito 2016). This pattern of religiosity first appeared in the second half of the nineteenth century, but reached a peak in popularity after decolonization, in the face of failing western-style modernization projects and ideologies. Adherents of Islamic revivalism often criticize so-called religious innovations (bid 'a) associated with popular Islam or Sufism. They also engage in educational activities promoting the (re-)establishment of Islamic law and various political agendas ranging from radical jihadism to moderate Islamic liberalism.

As French political scientist Guilian Denoeux (2002: 58-69) shows, the latter group of Islamic movements and organizations is known for selectively emphasizing presumed fundamentals of Islam and employing them for ideological purposes. Therefore, it is hard to associate these movements with stable political regimes. On the other hand, linking them with the normative, judicial dimension of Islam would also be counterproductive since ulama form just a small portion of Muslim societies. More importantly, throughout history, they have been known for being constantly subjugated by different political powers (Munson 1993). So, it is hard to analyse legalistic Islam as a politically independent entity.

\footnotetext{
5 In the Moroccan context, the term marabout should be mentioned, as well. Specific to North Africa, it refers to Sufi leaders or saints who are believed to have received barakah 'blessing' from God, which they are able to pass on to their followers, notwithstanding whether they are dead or alive. Marabouts are at the centre of popular Sufi mausoleum and moussem 'religious festival' culture (Marabout, The Oxford Dictionary of Islam).
} 
Thus, we turn further to non-legalistic Islam. Holding the sympathies of rural populations and opportunities to mobilise members of Sufi organisations, this form of Islam may be important in facilitating political stability. What is more, notwithstanding varying degrees of historical political engagement, some authors already argue that contemporary Sufi organisations or their offshoots can successfully act as peaceful socio-political movements in diverse contexts (Arifianto 2012; Barton 2005).

Taking into account the abovementioned assumptions, this paper will focus primarily on non-legalistic Islam and its relationship with the Moroccan monarchy as a factor possibly facilitating political stability in the country.

\section{EXPLAINING THE INTERPLAY BETWEEN RELIGION AND POLITICS}

In the second half of the twentieth century, a number of Western anthropologists, including Clifford Geertz, Elaine Combs-Schilling, and Ernest Gellner, conducted fieldwork in Morocco. These scientists researched the impact of colonialism and modernity on Moroccan society, and dealt with large-scale changes that were provoked, firstly, in religious and political spheres. Since the segmentary theory of Ernest Gellner proved useful in recent fieldwork for the identification of a spectrum of religious actors, it is presented below, followed by an overview of the "Governance of Religion" approach, which helps to broaden the list of actors and address different strategies of political interaction.

According to Gellner (1992: 23), by far the most evident characteristic of Islam, in general, is its division into low-popular and high-elite spheres. High tradition is connected with ulama, and has authority over urban bourgeoisie making their living from trade and handicrafts. Gellner (1992: 23) claims that high Islam represents the values and inclinations of this group: creating and abiding by rules, and preserving order and sobriety. Therefore, it is a strictly monotheistic model of Islam, oriented towards studying religious scripts and not aiming to mediate between believers and God. High tradition criticizes emotionality and the audio-visual aspects of the low-popular Islam that is important for the inhabitants of the rural peripheries (in the case of Morocco, those living in Atlas, the Rif Mountains, or surroundings of the Sahara Desert).

On the contrary, for groups adhering to low-popular Islam, amulets, ritual magic, religious ecstasy, and the esoteric aspects of Islam are more important than the Quran or other religious scripts. This model is orientated towards mediation: low tradition is important in the periphery, because it provides symbols by which illiterate adherents can passionately identify themselves with mainstream orthodox Islam. Gellner (1992: 29-30) himself phrases it as follows: "If opium is indeed required for the people, then ecstatic mysticism serves better than scholastic theology". He also quotes Émile Durkheim, noting that inhabitants of the periphery need a religion that can provide them with markers of time and space, boundaries for societal sub-groups, and seasonal works. Low-popular Islam meets all of these needs.

For Gellner, an intrinsic form of low-popular Islam can be observed in the activities of Sufi turuq. Gellner argues that, in the periphery, sheiks of these organisations can function as or substitute for ulama, the clergy of high Islam. Moreover, he notes that local communities in Morocco are even partly organised by Sufism, since Sufi organisations and their sheiks often act as patrons towards them. (Gellner 1992: 26)

In Gellner's work, the division between low-popular and high-elite Islam is juxtaposed with the ideas of one of the most prominent English social anthropologist, Edward Evan EvansPritchard, who analysed the regulation of social order and political life in so-called "stateless 
societies". He developed a segmentary theory primarily for Nuer tribal entities in South Sudan. (Tobolka 2003: 89-91) Gellner revised this theory for the analysis of Islamic societies (Munson 1993). A scheme, developed according to his adaptation, is presented below (Fig. 1).

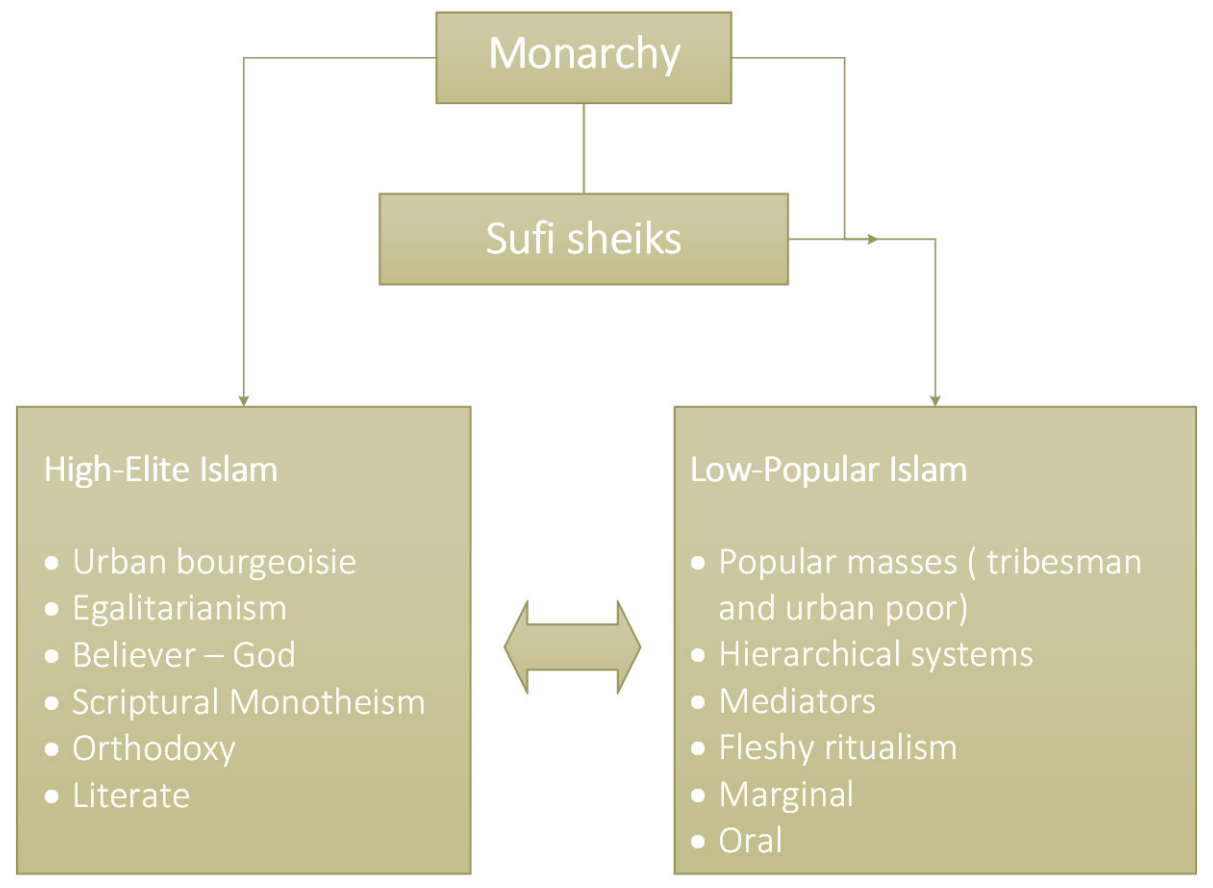

Figure 1 Segmentary theory

The model of segmentary theory is based on the principle of the pendulum (Morris 2006: 98-99). This means that in the Moroccan periphery, a historical aspiration to "purified" high Islam was always present. Therefore, a number of dynasties aiming to reform Moroccan Islam invaded central territories and cities of the country. Nevertheless, following these invasions, the rebel commanders became saints or sheiks themselves most of the time. Consequently, Gellner's pendulum returned to the traditional balance between the two opposing segments.

City inhabitants, according to Gellner, are not always ignorant towards Sufi activities. At the same time, adherents of low Islam may even feel respect for the high Islamic tradition, without giving up their own religious rites. What is more, differences here may only be minor ones and may not pose any obstacles for the peaceful cohabitation of the two groups. Using Gellner's own words, dialectic interaction between low-popular and high-elite Islam has only created conditions for "a repetition and rotation of personnel in an unchanging social order". (Gellner 1992: 24-25)

A special place is reserved in Gellner's theory for the charismatic religious leaders of Sufi organisations and the social and political arbitration of Sufi sheiks in the Moroccan periphery. This special status is based on their claims of being sharif, descendants of the Prophet Muhammad, shared with the ruling Alaouite dynasty. ${ }^{6}$ The king of Morocco takes the title of

\footnotetext{
6 Not to confuse with 'Alawites, adherents of an extremist Shi' i school of thought, found in north-western Syria, or Alevis in Turkey practicing a syncretic version of Shiite, Sunni, and Sufi Islam. The Alaouite dynasty is the current ruling family of Morocco, claiming descendancy from the Prophet Mohammed through the family line of his daughter Fatima Zahra. For further discussion, see Waterbury 1970.
} 
Amir al-Mu'minin 'commander of the faithful' because of the same presumed descendancy from the Prophet. In this sense, the monarchy shares a similar standpoint with the sheiks of Morocco's Sufi turuq. As Gellner argues, this similarity empowers both actors to play the role of arbiter in disputes between societal groups separated by various social, religious, ethnic, or tribal cleavages. In critical periods, arbiters help to politically unite different societal segments through personal charismatic appeal associated with a presumed sacred family line (Morris 2006: 97-98). Some authors, including Clifford Geertz even argue that monarchy is "the key institution in Moroccan religious system" (Geertz 1971: 75).

Thus, segmentary theory can be used as a model for explaining the cohesion of Moroccan society and the sustainability of its social contract with the monarchy. Sufi sheiks may be seen in the middle of the segmentary dynamic, whereas the king, as a sharif, also shares a special relationship with them, while overseeing both political and religious aspects of the social life. Nevertheless, one should not overlook criticism by other authors, who assess the segmentary dichotomy provided by Gellner as being rather vague, simplistic and inadequate (Račius 1997: 184-188). According to some, Gellner's theory ignores the different overlaying roles of actors situated on different sides of this "pendulum" (Morris 2006: 99). Gellner's theory proves to be counterproductive for two more reasons:

1. It is not compatible with the large-scale structural changes that have been transforming Moroccan society since the end of the twentieth century: mass migration, commercialisation, urbanisation, westernisation, the rapid growth of tourism, and so forth (Pargeter 2009: 1042).

2. Consequently, segmentary theory is not able to grasp the complex religious environment, including a large number of different actors and ideas, produced by these changes. In addition, it does not allow one to identify the different, largely contradictory strategies employed by the state and various religious groups while regulating their interactions.

Consequently, a new, updated approach is needed. IMISCOE network scholars Marcel Mausen and Veit Bader (2011: 7-27) suggest a governance approach, which has been successfully used in the analysis of complex cases in other scientific milieu (for example, European Union studies), and start their argument with the critique of traditional theories, paying special attention to the state vis-à-vis various religious actors.

According to Mausen and Bader, theories focusing primarily on the role of the state have been created for the analysis of European or Western cases, emphasizing hierarchical structures of subordination and rules of various kinds. A traditional example of these theories is the model of bureaucracy proposed by Max Weber. In the employment of such models to analyse the state-religion relationship, attention has until recently been mostly paid to the laws and formal rules that governments use to regulate religious groups. In colonial and postcolonial contexts, Mausen and Bader argue, one can easily spot the shortcomings of this approach: relying on these theories, only the external regulation by colonial states is analysed. Therefore, the heterogeneity of regulated actors, their strategies towards the state, and their inner contradictions and tensions are not included in the scope of the research. (Mausen, Bader \& Moors 2011: 16) What is more, a clear separation is not made between the existence of some regulatory strategies and their actual effectiveness.

According to Mausen and Bader, a visible alternative in this situation is the model of governance that has recently been becoming more and more popular amongst scientists from neighbouring disciplines. It allows researchers not only to analyse decisions of public policy, but also enables them to consider and evaluate regulation of different kinds. This means that 
this sort of analysis includes not only laws and decisions of the state, but at the same time also any other capacities enabling regulation, self-regulation, and co-regulation of actions by the state and various religious groups. (Mausen, Bader \& Moors 2011: 16-17)

As Mausen and Bader note, this definition of governance frames it as very broad concept, and consequently is very useful in analysing relations between states and societies. Governance focuses as much attention to external as to internal regulation. It prevents ignorance of the tradition of networking between Islamic organisations and associations, and enables the inclusion of various new aspects in the research: for example, the co-optation of religious leaders or transnational attributes of Islam (pilgrimages, traveling religious scholars, Sufi organisations, transnational heritage of colonialism, and so on). Mausen and Bader (Mausen, Bader \& Moors 2011: 17) stress that while employing the "Governance of Religion" approach, some or all of the following aspects should be taken into account:

1. Religious education: education of ulama, administration of madrasa 'religious schools', integration of Islamic education in public schools, outreach activities of Sufi organisations and state reactions towards them.

2. Policy of religious property: collection and administration of zakat 'obligatory alms' and sadaka 'voluntary charity', financing of religious institutions, policy of burial, and mosque construction.

3. The role of Islam in public life: codification and acknowledgement of Islamic law, relationship between Islamic law and customary law, integration of Islamic principles in family law and criminal law, administration of Islamic courts.

4. Platforms and councils of Islamic self-governance.

5. Policy towards religious practises: organisation of pilgrimages at the state level, Islamic dress code, public fasting, organisation of religious festivals (for example, birthday of the Prophet Muḥammad).

6. Islamic practises and strategies of different religious groups that are not obligatory for the whole society.

7. National identity building: the role of Islam in fighting colonial powers and establishing modern national narratives after decolonisation.

As the fieldwork demonstrates, the combination of the abovementioned theoretical approaches helps to shed a light on the environment and social order in which Moroccan nonlegalistic Islam operates, and allows a better understanding of various overlays and incentives to regulate relations between religion and the Moroccan monarchy. Before the presentation of the analysis based on these approaches, historical context is given in the following section on the Moroccan monarchy's approaches to Sufi organisations and to non-legalistic Islam, in general.

\section{THE HISTORICAL CONTEXT}

A strong presence of Sufi brotherhoods in the Moroccan politics has been felt ever since their appearance in the beginning of the eleventh century (Muedini 2015: 67). The whole period of Moroccan history before colonisation in 1912 was characterised by a distinction between bled al-makhzen, centralised areas ruled by the monarch, and bled s-siba, the semi-independent periphery of Morocco (Gellner 1969). As already mentioned, Sufi brotherhoods were mediators in this context between high-legalistic Islam and illiterate masses. Moreover, they articulated the interests of the periphery, and consequently established their own social and political status 
(Ghoulaichi 2005). In a society divided by various cleavages, Sufi sheiks had a substantial popular support that enabled them to either openly oppose or, conversely, to substantially support the central government.

For example, Alaouite sultans in the late 1600s and early 1700s largely relied on the Nasiriyya brotherhood, which played an influential role in local trade, collected toll taxes, provided credits for merchants, and owned land, water resources and similar infrastructure. Taking this into account, sultans made sure that Sufi brotherhoods and their leaders would not be bothered by state interference in their affairs. Support of Sufi brotherhoods like Nasiriyya allowed the central government to have a tighter grip on otherwise fragmented political field and to mobilize its subjects for jihads against the Portuguese, who were at the time trying to establish themselves on Moroccan shores. (Muedini 2015: 68) Later, as the country gradually became more exposed to international trade, Nasiriyya's influence diminished and other turuq became more prominent (Darqawiyya, Wazaniyya, Tijaniyya - to name a few).

Over the course of the nineteenth century, Morocco slowly fell under the command of European powers. In this environment, political postures of different Sufi brotherhoods diverged. A good illustration of these ambiguous relations is the position expressed by Sultan Moulay Slimane, who ruled in the beginning of the nineteenth century. Slimane publicly denounced Sufi organisations as being outside the bounds of Islamic law and blamed them for blasphemy and for ruining the morals of Moroccan people. Another interesting example is Moulay Abdessalam, sheik of the Wazaniyya tariqa, popular in the north of Morocco. By the middle of the same century he was already co-operating with the Europeans. While seeking political influence, he became one of the candidates to take the Sultan's place, in case of an intervention by the French (Ghoulaichi 2005: 17). Finally, the most radical example comes from 1908, when Mohamed ibn Abdelkabir al-Kettani, a leader of prestigious Kettaniyya tariqa in Fez, released a public statement about the responsibility of Sultan Moulay Abdelhafid for the growing foreign influence in the country. In response, Abdelhafid at first attempted to form an alliance with al-Kettani, co-opt him, and quiet the dissent. Since this strategy proved unsuccessful and al-Kettani attracted even more supporters of his anti-colonial and anti-establishment critique, he was arrested and tortured to death. This was followed by suppression of the Kettaniyya tariqa (Muedini 2015: 69).

Algerian-French sociologist Addi Lahouari (2009: 332) argues that the marginalisation of zawiya Sufi 'lodges' and mausoleums of saints was one of the most visible changes in the Moroccan society during the period of colonisation. He also explains that, while Moroccans were opposing colonial powers, ideas of Salafism, which can be attributed to Islamic revivalism, were gaining more and more support. Religious scholars, preaching for spiritual revival and purification, were the main figures in this process. Consequently, non-legalistic Islam was portrayed as backward, downgrading the morals of the nation, and was blamed for the European influence in the country. And indeed, some Sufi turuq did collaborate with foreigners. In contrast, ulama, representing legalistic Islam, actively promoted reestablishment of a strong monarchy. Therefore, it gained support not only amongst the popular masses, but within Moroccan elites, as well.

In the second half of the twentieth century, Morocco, under King Mohammed V, regained its independence. Hassan II, the father of current king Mohammed VI, became the ruler of the country in 1961. Hassan II introduced a reform of religious centralisation, which once again was not in favour of Sufi turuq and their independence from the state. Maintenance of mauso- 
leums and zawiya, previously carried out by sheiks of Sufi groups or their family members, was transferred to a special newly created niqabat shorfa 'commission of holy descendants', which came under the surveillance of the Ministry of Interior. Besides that, Hassan II sought to reduce the influence of Sufi organisations, while establishing new religious institutions that would be able to compete with the traditional centre of Moroccan Sufism, Al-Qarawiyyin University in Fez. Consequently, the state-owned religious school Dar al-Hadith al-Hassaniyya in Rabat and departments of Islamic studies at public universities were opened (Chih 2012: 27). Hence, during the rule of Hassan II, the religious sphere was centralised and certain institutions were created to ensure surveillance of Sufi groups and the influential families gathering around them. The potential for political opposition from Sufi turuq was diminished, and ways for these organisations to express themselves became more limited.

In contrast, Mohammed VI, whose rhetoric towards Sufism is incomparably different to those discussed above, rules the Kingdom of Morocco today. Mohammed VI associates Sufism with pacifism and high individual morals. What is more, the current king personally takes part in rituals that may be attributed to Sufism (Chih 2012: 43). For example, he frequently visits different zawiya. Sufi conferences and gatherings often start with a word from the monarch. Even the son of the king was officially circumcised in Fez, in the zawiya of Moulay Idris II.

Moroccan scholar Fatima Ghoulaichi (2005: 4), alongside other scientists, stresses that relations between Sufism and the Moroccan monarchy have been reformulated after the tragedy of 9/11. Moreover, she claims that Sufism became a cornerstone of an antiterrorist strategy of the country. In this context, a date of special importance is 16 May 2003, when a terrorist attack in Casablanca highlighted the problem of youth living in the shantytowns of big Moroccan cities. Young people from these areas formed the base for "Salafia Jihadia", a radical terrorist organisation responsible for the abovementioned attack. Reacting to the outbreak of terror, the young king, at the time having ruled for only four years, initiated a religious reform, which included a reorganisation of the Moroccan Ulama Council, rehabilitation of traditional madrasa and a review of Islamic programmes at public schools. According to Ghoulaichi, who carried out extensive research on public speeches given by the king after terrorist attacks in Casablanca, Sufism in his rhetoric is portrayed as a counterbalance to violent radical Islam. Mohammed VI also calls for a revival of Sufi traditions in the country, and describes it as a normalisation of the religious situation. (Ghoulaichi 2005: 29-39)

Taking into account the discussed dynamics, an active attempt to revive traditions of non-legalistic Islam seems like a logical step for the government. Sufi groups have limited opportunities to be politically active and therefore do not have any chance to directly oppose the monarchy, even though, historically, they were able to refuse official policies of the ruling dynasty.

\section{THE MANY FACES OF NON-LEGALISTIC ISLAM}

As shown above, despite having a long common history, Moroccan monarchy and actors of non-legalistic Islam have only recently re-established positive relations. Findings of the fieldwork point to two main dimensions defining their relation today: first, the axis of traditional and reformed non-legalistic Islam, and second, the axis of bottom-up and top-down incentives for its re-establishment. Further, it is argued that only a small part of today's Moroccan religious landscape can be grasped using segmentary theory as put forward by Ernest Gellner. Instead, an interpretation of gathered data, complemented by the "Governance of religion" approach, is suggested. 


\title{
Moroccan Monarchy
}

The starting point for discussing the findings of the research is focused around the role of the king as a religious leader and a central institution affecting Moroccan religious life. The 1962 constitution of the country awards the king the title of Amir al-Mu'minin 'commander of the faithful'. As mentioned previously, this title is based on the belief that the Alaouite dynasty has a blood link with the Prophet Muhammad and his family. It is important to note that there are many Moroccan families claiming to be sharif. ${ }^{7}$ For example, all sheiks of traditional Sufi organisations and even some respondents in this research, not associating themselves with nonlegalistic Islam, identify themselves as sharif. Therefore, this title is not a royal exception. Moreover, a majority of informants saw it only as a remnant of the past.

A much more relevant characteristic of the Moroccan monarchy today is its political power and subordination of religious elites. For example, Mohammed VI is the head of the Moroccan Ulama Council. As one respondent phrases it:

\begin{abstract}
The religious sphere is pretty much monopolised by the monarchy; you cannot come up and say I have a fatwa and it is completely Islamic. No. If it is not approved by the council that is assigned by the king, you are not going to get it. There is no religious vacuum; there is no religious space for opponents, from a religious point of view, to function. (A male student of international studies at a private university, Fez, 18 Mar. 2015)
\end{abstract}

Thus, it can be assumed that Mohammed's VI religious authority rests less on the mere existence of the traditional title, and more on certain governance instruments applied for regulating the religious sphere.

\section{Traditional Non-Legalistic Islam}

An object of interest for this study, non-legalistic Islam, as previously explained, can be divided into two different, but interconnected, parts: (1) Sufism as a vast network of orders and brotherhoods, advocating personal piety through organised ritual practise; and (2) more eclectic popular Islam, associated with a cult of local saints, their mausoleums and popular religious festivals. Informants in this study primarily define non-legalistic Islam with the historical characteristics of Sufism, and more particularly, by its ability to mobilise followers while seeking political goals:

Through history, political powers, political were taking power from the religion. Moulay Idris when he came to Zerhoun[...] so he set up a zawiya, he is gathering followers and through these followers, he has political and ideological power that enable him to have a pressure on the sultan, on the other tribes. (21-year-old male cultural entrepreneur, Fez, 15 Mar. 2015)

However, it would be wrong to claim that Sufi organisations are no longer relevant. During the interviews, the names of different active traditional Sufi organisations (Tijaniyya, Darqawiyya, and Shadhili) were mentioned frequently and respondents claimed that they are known within the society. On the other hand, it is generally agreed that traditional Sufi turuq are not successful in attracting new members and largely rely on families of their members for finding new recruits:

7 Henry Munson (1993) gives a reasonable explanation and compares the title of sharif with the titles of

European nobility that throughout history were sold, awarded, or exchanged. 
Mostly, they did not choose that, it is because their family belongs to the zawiya, to the tariqa, so they ended up belonging. It is more or less a family tradition[...] it might be a social tradition, belonging to a Sufi tariqa, it might be a micro-level tradition. (A male student of international studies at a private university, Fez, 18 Mar. 2015)

A special characteristic of Sufism, in general, especially evident in the Moroccan context, is what we can define as "horizontal harmony". It means that tensions between different Sufi organisations and their sheiks are very unlikely, not only because of their peaceful ideological stance, but also due to the same presupposed descendance of all Sufi sheiks, linking them with the family of the Prophet and the monarchy. As a tijani imam explains:
You know, all the shrines in Morocco, all the masters come from Al-Bayt [Prophet's family] and they glorify Sidi Ahmed Tijani, because he is the fourth son of the Prophet. All the paths, all Sufi paths are the same, maybe they share the same $d h i k r$, chanting $[\ldots]$ and there are some differ- ences in some places in a way of worshipping God[...]. All people affiliated to another Sufi path, Budshishiyya or Tijaniyya, they are brothers, as one person. (A tijani imam, Fez, 22 Mar. 2015)

How do traditional Sufi organisations function today? Findings of the fieldwork point to two main directions of their activities: First, Sufi turuq can be identified as institutions of spiritual education, where followers gather to learn from the sheik and to be initiated into the ranks of other companions; second, as some informants put it, they can be a place where one goes to seek the blessing of a spiritual leader. The latter option may be more important in case of illiterate popular masses, and the first one - urban populations.

Moreover, the spiritual aspects of Sufism today can still be outweighed by its practical capacities, especially relevant while organising social life in the periphery:

It is the centre of all "when problems get solved": problems of water, problems of family, religious education. If anyone needs some information or has some issues of religious education, they go the sheik. It is not only the educator, but more of the manager of the town. The social role is more apparent, I would say, than spiritual role, because at the end of the day, spiritual teachings are accustomed to the needs of the town. (A male student of international studies at a private university, Fez, 18 Mar. 2015)

The "centre of all when problems get solved" role of Sufism largely corresponds to arguments developed by Ernest Gellner and summarised by his segmentary theory. Even today, in rural areas, as one respondent argues, the state is up to a certain degree absent and the social vacuum is filled by Sufi organisations. Consequently, a question arises. Does this process also include a political dimension, as suggested by Gellner? Findings prove that the Moroccan monarchy and actors of traditional non-legalistic Islam are, in some cases, dependent on one another. For example, in remote Moroccan areas some social and practical functions, like education, family advising, or arbitration in local disputes, can be provided by local Sufi sheiks and organisations. In the case of central areas of Morocco, these would be the responsibility of the state. Thus, we can assume that Sufism may become a sort of substitute for the state. Nevertheless, we cannot say that the state is not present in any way. Moroccan monarchy funds active Sufi organisations and this may be partly due to the need to provide the aforementioned services to the populations of the periphery. Assistance provided by the palace may also be seen as an instrument, urging Sufi organisations to modernise:

Yes, the king sometimes goes and gives donations to muqqadam of the Sufi orders, lots of support but the condition, of course, is that they recognise that the king is the "commander of the faithful" and that it should be done within the principles of Islam[...] If there is any opposition, they are 
never on the surface, so things are going smoothly, because Sufi orders make sure that Sufi orders do not deviate from the framework of Islam. (A middle-aged male professor of English and Moroccan Cultural Studies, Fez, 17 Mar. 2015)

In this way, the Moroccan monarchy acts as a patron of Sufi turuq. Funding from the state adds to the income from donations. It mainly benefits the sheiks (and their families) who are responsible for administrating the budgets of Sufi turuq. In return, the state indirectly fulfils its duties towards rural populations (by ensuring that Sufi organisations provide needed services) and seeks for religious and cultural modernisation in the periphery.

Moreover, a more recent trend mentioned by at least several respondents suggests that Sufism is getting more and more important as a tool of "religious diplomacy". This means that Mohammed VI successfully uses transnational networks of Sufi turuq with Moroccan origins to establish himself as a regional leader. As one informant elaborates:

\begin{abstract}
The other thing that I would like to say that is important, that is becoming more important over the last three or four years, it is how Morocco, especially the king of Morocco, Moroccan diplomacy starts to invest in this Sufi legacy. It has with Africa, particularly through all the Sufi orders. Tijaniyya[...] they played a very important role while preaching Islam in Africa. So, the king of Morocco as the "commander of the faithful" goes to visit[...] Whenever he went to visit Cote d'Ivoire, Gabon, Senegal, Mali and other countries, he goes, of course, as a statesman to sign economic agreements, but also as a "commander of the faithful". He does not meet only the presidents, but he makes sure, over the last two years, he made sure to visit the sheiks of the major Sufi orders in these countries. (A middle-aged male professor of English and Moroccan Cultural Studies, Fez, 17 Mar. 2015)
\end{abstract}

The Sufi organisation Tijaniyya is the best example of this, since it is relevant in two different contexts. First, it is the biggest and most influential Sufi organisation in Sub-Saharan Africa and attracts many Africans to the Zawiya of Sidi Ahmed Tijani in Fez. Secondly, it is also widespread amongst African Americans living in the United States of America. Therefore, a legacy of Moroccan Sufism may be an appealing instrument while formulating the country's foreign policy. For example, it was used while arbitrating during the Northern Mali conflict in 2012-2015, when the king of Morocco was frequently meeting political and religious leaders from both opposing sides (Tadlaoui 2015). Moreover, as some respondents claim, it was also the reason behind the recent "export" of the Moroccan religious model to West Africa. To give an illustration, an Islamic studies programme opened recently at the prestigious Al-Akhawayn University in Ifrane, where Moroccan imams are being instructed in English in order to be sent to one of the countries in West Africa. Notwithstanding that, it is important that this foreign policy is acknowledged at the domestic level as well and plays a part in creating an image of the monarchy in the eyes of the wider Moroccan society.

The second pattern of non-legalistic Islam is popular Islam, defined by a cult of saints and various Islamic folk rituals. Findings of the fieldwork suggest that this pattern is growing less important, since a majority of respondents claim that it is largely considered as bid'a 'blasphemy' and attributed to rural populations:

\footnotetext{
I feel like a zawiya is something that comes with Islam, but Moroccans make it more economic than religious. Some people go to zawiya and they give some money to the one who is there and ask for a child, more wealth, and more health[...]there is like a box[...]. For me it is something not from the basics of Islam. (A male student of Law, Fez, 16 Mar. 2015)
}

On the other hand, symbols of popular Islam such as mausoleums of local saints, and the moussems or 'festivals' organised around them attract lots of foreign attention. Interestingly, 
they attract royal attention, as well. Some informants noticed that recently moussems have been getting bigger and bigger and mausoleums are being extensively renovated throughout the country. Others also pointed out the reasons behind this:

\begin{abstract}
You know that all the Sufi paths from all over the world come here: Budshishiya, Tijaniyya, Darqawiyya[...] Sufi paths in the Middle East come here to visit the shrine of Moulay Idris, because you know[...]. because for Sufism, if you do not like Al-Bayt, the family of our Prophet, you are not a real Sufi, you should like every member of Al-Bayt, of our Prophet's family. Our king Mohammed VI, he gives a financial gift every year to all shrines here in Morocco. Because our King, he said that Moulay Idris is his grandfather, so[...]. (Muqqadam, 'keeper' of Zawiya Moulay Idris II, Fez, 22 Mar. 2015)
\end{abstract}

Thus, interest in religious tourism and the previously mentioned presupposed descendance of saints, sheiks and the Alaouite dynasty provides an explanation for the degree of attention the state currently pays to popular Islam.

Summing up, the interconnectedness of Moroccan monarchy and traditional non-legalistic Islam is evident. Paramount to it is the delivery of some social services by Sufi organisations in the Moroccan periphery, partly backed up by state funds. Nonetheless, this cannot be viewed in the context of questions about political stability nation-wide, since traditional Sufi groups do not have the intentions or capacities needed to reach out and recruit new members from wider Moroccan society. Segmentary theory, as put forward by Ernest Gellner, is suitable for analysing findings of the research provided so far, especially in trying to comprehend the different roles of non-legalistic Islam in urban and rural environments. However, this is where it reaches its analytical limits. Therefore, further a new term is introduced: reformed non-legalistic Islam.

\title{
Reformed Non-Legalistic Islam
}

In the following sections, three different actors representing the spectrum of present Moroccan non-legalistic Islam (due to its shifting characteristics, we will define it as reformed nonlegalistic Islam), are discussed: fluid neo-Sufism, the reformed traditional Sufi organisation Budshishiyya, and its offshoot organisation Al-'adl wa al-Ihsan. All of them differ in terms of organisational integration and stance towards the central government, ranging from co-optation to moderate opposition.

\section{Neo-Sufism}

French scholars Patrick Haenni and Raphael Voix provide a valuable account of current trends in modern Moroccan religiosity. They argue that interesting dynamics are visible not only in the relationship between the monarchy and Sufi organisations, but that they are also an outcome of inner processes within Moroccan Islam itself. Haenni and Voix (2007: 244-245) claim that there is an unnoticed process of Islamisation taking place in Morocco, especially evident in the case of Moroccan bourgeoisie. Much like non-legalistic popular Islam, this Islamisation is a fluid phenomenon defined by eclectic religiosity, based on a reinterpretation of Moroccan Sufism or its fusion with other non-Islamic religious practices. As noted by Haenni and Voix, it is similar to New Age religious movements, which reached their peak of popularity in the West during the 1970s.

In other words, some claim that there is a new type of non-legalistic Islam currently emerging within Moroccan society. It is strongly concentrated on the normative dimension, defined by 
values like peace, love and tolerance, and justified by the tradition of Moroccan non-legalistic Islam. Nevertheless, juxtaposition here is not possible, since the main actors in this case are not hierarchical Sufi organisations, but rather what may be defined as "spiritual seekers", individuals, both males and females, searching for "ethical" Islam (Lofland \& Skonovd 1981). Therefore, self-realisation, inner balance and spiritual peace also make up a part of the normative background in neo-Sufism:

Young people are interested in getting close to Sufism, in the sense when Sufism is not representing any tariqa, but is representing the spirit of spirituality, freedom, openness and tolerance to the other[...] As we see in occidental countries. (21-year-old male ex-member of Budshishiyya tariqa, Fez, 15 Mar. 2015)

Accordingly, neo-Sufism should be discussed with the "privatisation" of Islam trend in mind. Moreover, the ways in which members of the wider society engage in it are different, as well. As Haenni and Voix show, these practices attract interest as a part of modern public discourse, again not something associated with traditional Sufism. This trend is explained by the fact that most of the current Moroccan bourgeoisie grew up in secular families, went to French-style lyceums and still are under the influence of Western culture. Therefore, neo-Sufism reaches them through alternative channels. (Haenni \& Voix 2007: 243) Findings of the fieldwork also support this argument. For example, one informant, whose curiosity about Sufism eventually became only an academic interest, explains:

I got interested [in Sufism] through learning about Buddhism. Nobody would believe that, maybe some. I discovered it through Buddhism. Sufism somehow gives an answer; it tells you do not need to reflect too much about it. It is somehow like yoga or Buddhism became famous in the West: you do not need to have a dogma, you do not need to go and worship Buddha for your meditation. Some people may go just for the hadr [trance], but never pray. (A male student of international studies at a private university, Fez, 18 Mar. 2015)

The experience of the informant is also in line with the arguments of Haenni and Voix (2007: 245-246), who highlight a paradox: Moroccans are often introduced to Sufism by European converts to Islam, and also by members of the Moroccan diaspora or affiliates of various New Age religious movements. In this way, through neo-Sufism, Moroccans are able to find a substitute for attractive, but non-Islamic religious practices, which may be popular in the Western context, as well, such as the Buddhism mentioned in the example above.

Summarising previously mentioned tendencies, one should note that neo-Sufism in Morocco is not institutionalised. It operates at the level of the individual, who probably performs Sufi rituals by himself or herself, for example practising $d h i k r$ 'repeating the names of God' combined with spiritual practices of other Eastern cultures, such as yoga or meditation. As the findings of this study also suggest, neo-Sufis do not stress the need to belong to a particular organisation, but appreciate the general spiritual atmosphere. This shift in emphasis makes the concept of neo-Sufism much broader than its traditional definitions.

What is the monarchy's response to a shift in the religious landscape of the country? Mohammed VI made a wise political recourse, since he unilaterally declared Sufism as one of four "cornerstones" of Moroccan Islam:

There is this recourse, officially (!) on the part of the king, directly on the part of the king, to adopt Sufism, Sunni Sufism as one of the four cornerstones of Moroccan Islam. In a speech, in a royal speech, he talks about how Sufism is one of the cornerstones of Moroccan Islam[...] so the main cornerstones are ash 'ari, maliki, and the king as the "commander of the faithful", the fourth corner- 
stone is Sunni Sufism. (A middle-aged male professor of English and Moroccan Cultural Studies, Fez, 17 Mar. 2015)

But what sort of Sufism is this from a normative point of view? As argued by Moroccan scholar Fatima Ghoulaichi (2005: 45-46), the Moroccan monarchy selectively reconstructs the very idea of Sufism, while "depicting the [Sufi] saint as a traditional supporter of the Sharifian monarchy[...] restoring the image of Moroccan society as an open, tolerant one, that is practicing a moderate form of Islam". Off course, this depoliticization of Sufism contradicts the ambiguous history of relations between the monarchy and Sufi brotherhoods. On the other hand, the monarchy's ideas about religious liberalism echo and, up to a certain extent, reconcile expectations of some middle and upper class Moroccans, who may adhere to some aspects of neo-Sufism, and encourage their faith in the "re-emergence" of a moderate national religious culture in the midst of contemporary perturbations. A few informants also named an example of this transition: the state religious media platform "Assadissa", which promotes both an image of Mohammed VI as a religious leader and a version of Moroccan Islam that integrates liberal and moderate aspects shared with neo-Sufism:

\section{And this, in fact, the "Assadissa", the radio "Assadissa", also the TV channel[...] it is attracting more and more audience in Morocco, but it stresses that the king is the "commander of the faithful" and this version of Moroccan Islam, which is tolerant, peaceful and in the middle. (A middle-aged male professor of English and Moroccan Cultural Studies, Fez, 17 Mar. 2015)}

This attempt of the Moroccan monarchy to portray itself alongside moderate religious lines largely resembles the concept of $d a$ 'wa Muslim 'missionary activities' (Račius 2005: 97-102). As argued by Račius, once employed by state actors, da'wa can also function as an ideology, legitimising their actions. Therefore, we can suppose that Sufism, and neo-Sufism, in particular, may be included in the newly found formula of Moroccan Islam for certain political purposes. As some informants point out, Sufism benefits the monarchy, as well as the whole society. This royal recourse may facilitate political stability by providing an alternative to violent interpretations of Islam:

I think it is good for both. It is good for the king and the government to maintain religious power and good also for the society to spread openness, religious openness and tolerance, because otherwise there will be religious fanatics, which make, like, lots of conflicts within the society and between society and the power, as it is happening in Iraq. (21-year-old male cultural entrepreneur, Fez, 15 Mar. 2015)

Summing up, we can argue that neo-Sufism is a much broader concept than it was traditionally defined. Consequently, it can be easily adapted for various political purposes. In the case of Morocco, Sufism, in its updated definition, is employed by the monarchy to spread tolerance and openness within society. It should also be noted that some segments of the Moroccan society, the bourgeoisie, in particular, because of modern and liberal orientations, may themselves see it as a more attractive alternative form of Islam. Therefore, one could claim that the recent emergence of neo-Sufism should be defined as a co-regulation of religious sphere, both a top-down and a bottom-up process (Mausen, Bader \& Moors 2011: 15-18). 


\title{
Tariqa Budshishiyya
}

Is the abovementioned societal and royal recourse to neo-Sufism reflected by traditional Moroccan Sufi organisations? Findings of the fieldwork suggest that the answer, at least in the case of tariqa Budshishiyya, is affirmative.

This Sufi organisation originated in the Berber-dominated North-eastern Moroccan province of Oujda. ${ }^{8}$ In recent decades, it has become prevalent across the whole country and has even transcended the borders of the kingdom and become transnational. Thus, in addition to the Berber peasantry, tariqa Budshishiyya gathers certain middle-class Arab populations coming from Moroccan urban areas and international adherents reached through migratory channels. Anthropologist of religion Marta Dominguez-Diaz has done a considerable amount of fieldwork researching women's participation in Budshishiyya. In the manner of sociologist Zygmunt Bauman, she defines this tariqa by its "liquid" forms of relating (DominguezDiaz 2011: 1-15). Dominguez-Diaz's definition largely corresponds to previously discussed characteristics of neo-Sufism; therefore, further we analyse Budshishiyya as a phenomenon of reformed non-legalistic Islam.

The majority of informants identified a shift in Budshishiyya's organisational structure, distancing it from other traditional Sufi organisations, as a cause of its popularity and recent growth. As one of them explains:

\begin{abstract}
The other important thing is that the Sufi order Qadiriyya Budshishiyya is interested in going to the youth, going to people, not letting the people come to look for the sheik, for the guide to the Zawiya. The tabarruk to tarbawiyya, that is very important, because when we talk about tabarruk, the blessing, baraka of the sheik, it means you go and kiss his hands and his relics are sacred, and you go to seek the baraka of the sheik. And lots of time people, who go to seek baraka, are illiterate people from rural areas, very miserable socio-economic condition, but the shift from tabarruk appeals to educated people. Now more and more people are interested, because it is about education, it is about spiritual tarbawiyya. And because of this, Budshishiyya has been able to recruit young people, especially from the universities. (A middle-aged male professor of English and Moroccan Cultural Studies, Fez, 17 Mar. 2015)
\end{abstract}

Thus, traditionally functioning as a gathering of the local spiritual elite, tariqa Budshishiyya grew into a mass movement of spiritual education, attractive for the youth and educated Moroccans, French-speaking elites. Accordingly, it also started moving away from old rituals attributed to traditional Sufism and popular Islam, in particular. As the same respondent phrases it, "the first thing when you meet Budshishiyya Qadiriyya - it is Islam. Islam first and then the esoteric dimension of it". In other words, Budshishiyya does not encourage visiting the graves of saints, self-mutilation or similar rituals. Instead, normative aspects of Islam, stressing egalitarianism and tolerance are highlighted. This, in turn, attracts members of the wider society and youth:

It appeals to the youth, because you know Budshishiyya is not concerned: if you are women, you do not necessarily need to wear the veil. They are not strict on the religious costume and you do not have necessarily to wear a beard. They, the Qadiriyya Budshishiyya, look like any secular person. If you do not ask and they do not tell you, you would never know that they are Sufi. (A middle-aged male professor of English and Moroccan Cultural Studies, Fez, 17 Mar. 2015)

\footnotetext{
8 One should note that Budshishiyya is an offshoot of Qadiriyya - one of the oldest tariqa in the world, tracing its history from the teachings of 'Abd al-Qadir al-Djilani (1077-1166), who lived and preached in an Iranian province of Djilan. Nevertheless, Budshishiyya's more immediate origins should be found in rapid expansion or "explosion" of Sufi brotherhoods in Morocco in the eighteenth century (Browers \& Kurzman 2004: 133-134).
} 
Since it is open to wider society, Budshishiyya also includes intellectuals and members of academia, who influence its development on their own behalf. Respondents in this study also stressed the role of certain individuals belonging to Budshishiyya. Therefore, it may be argued that Budshishiyya has multiple centres of influence, compared to traditional hierarchical Sufi organisations, which place sheiks at the very top of their structures. For example, most respondents stressed the importance of Faouzi Skali, a Moroccan anthropologist, who published a number of books about Sufism in French and currently heads several religious music festivals in Fez. Some authors even claim that Skali "translated Sufism into modern Moroccan language" (Chih 2012: 42):

Faouzi Skali, one of the paramount figures of this Sufi order, who has this idea of universalism. He believes in human values, global values[...] And because he was strongly influenced by Guenon, the most important thing about him is that there is one essence in all religions that brings everybody together. Therefore, this essence is similar; we should develop it instead of differences. (A middleaged male professor of English and Moroccan Cultural Studies, Fez, 17 Mar. 2015)

Hence, the idea of universalism is the most important for Faouzi Skali. Moreover, as the informant further explains, it is currently central to the whole tariqa. This peaceful and open approach to religion, as well as an open standpoint towards the wider society is also identified as the reason behind the increase in numbers of Budshishiyya's followers. Furthermore, Budshishiyya even may be defined as proselytising or trying to attract as many new members as possible:

It is one of the most powerful; it has the most followers all over the place[...] it believes in international dialog, it believes in globalisation, in modernity, in opening up to the world, peace in the world. So, it believes mainly in interfaith dialogue and they want recruits from all over the place. They do not think too much about, unlike the Salafists, for example, who think that the enemy is a Christian. (A middle-aged male professor of English and Moroccan Cultural Studies, Fez, 17 Mar. 2015)

In characterising Budshishiyya, one should stress several things. First, it is one of the most dynamic and fastest growing religious organisations in Morocco (Dominguez-Diaz 2015: 1-10). Its identity is formed by its legacy as a traditional Sufi organisation with values similar to those of neo-Sufism such as universalism, promoted by different influential figures within the tariqa. Its shift to mass education has resulted in growth and attracted the attention of wider society.

Consequently, in the context of this study, it should be asked whether the Moroccan monarchy sees Budshishiyya as a viable tool for facilitating political stability, and what techniques it employs for that cause. Here, informants largely agreed on the existence of an especially close relationship between the Moroccan monarchy and tariqa Budshishiyya. The use of state media for promotional purposes was frequently mentioned, including coverage of Budshishiyya's gatherings and daily activities. As one respondent explains, Budshishiyya's apolitical nature is "handy" while ensuring the stability of the monarchy:

I think that Budshishiyya brought something to its field, some kind of religious and political vacuum, that exists within Moroccan society. Simply, the apolitical aspect of Budshishiyya makes it a perfect institution: apolitical and religious, and it keeps spiritual meaning for people's lives - and that is exactly what the state needs. (A male student of international studies at a private university, Fez, 18 Mar. 2015)

Most of the practical examples of this special relation include "highly positioned people" belonging to tariqa Budshishiyya. Mainly, references to special status address budshishis controlling the Ministry of Religious Property and Islamic Affairs, and in particular, Ahmed Tawfiq and Ahmad Qustas, the minister and the chancellor, respectively at the abovementioned 
institution. Both have an academic background and hold these positions by a decision of the king (Chih 2012: 25-34).

As a paramount example of the monarchy's sympathy towards Budshishiyya, many interviewees noted the royal patronage awarded to festivals like Fez World Sacred Music Festival or the Sufi Culture Festival organised by Faouzi Skali. As highlighted by one respondent:

\begin{abstract}
The same foundation organises both festivals, "Esprit de Fez". Faouzi Skali, the main Sufi writer, manages it, and he is an important member in the Budshishi zawiya. You can understand why it is like having the royal support, we can say, because the two festivals are[...] royal, because it is related to politics and second that there is zawiya Budshishiya that is interfering in the affairs of the festival. There are many religious festivals: there is[...] which no one cares about, there is a festival of Andalusian music, many festivals that can take place in Fez. (21-year-old male cultural entrepreneur, Fez, 28 Mar. 2015)
\end{abstract}

Frequently, informants themselves referred to these festivals as global and transnational, and associated them with ideas of religious universalism. As some argue, through these festivals, modern Moroccan culture incorporates Sufism or neo-Sufism, as it was defined previously. It gathers worldwide audiences and creates an appealing atmosphere for the Moroccan youth (Bekkaoui \& Larémont 2011). Therefore, we can see a probable link between the royal patronage awarded for these festivals and the popularity of Budshishiyya amongst young Moroccans.

On the other hand, through this support, the Moroccan monarchy secures a solid partnership with an organisation with large capacities to mobilise its members. For example, in 2011, members of Budshishiyya participated in an ambiguous march for the new constitution proposed by the king as a reaction to the protests that took place in Morocco as a part of the "Arab spring" (Chih 2012: 45): 9

Yeah, the sheik, the leader asked them to go out in Casablanca from all Morocco and demonstrate for the constitution, because those people who were more westernised, they were protesting against, they were trying to boycott the constitution. It is one example, the love story of Sufism and the monarchy is so deep, you cannot image someone from Budshishiyya going out and saying - "Our monarchy is doing something bad". (A male student of international studies at a private university, Fez, 18 Mar. 2015)

Judging from the fieldwork findings, the identity of Budshishiyya was created without the interference of the state. Its open and tolerant agenda enables this tariqa to gain popularity within the wider society. On the other hand, after a previously mentioned royal recourse to (neo-)Sufism, Moroccan monarchy co-opted some of Budshishiyya's most influential figures and started providing patronage for some of its initiatives, which in turn resulted in support rallies organised by Budshishiyya, adding to the stabilisation of the political situation in the country. Therefore, both - monarchy and tariqa Budshishiyya - have their own incentives for establishing and maintaining this special relationship. In other words, the linkage described above is profound, because 1) Budshishiyya has immense organisational capacities; 2) it mobilized its members in support of the monarchy in a critical context of unravelling Arab Spring protests; and 3) this was as well preceded and followed by various rewards from the side of makhzen the 'royal palace'. In Morocco's case, during the process and the aftermath of the Arab Spring, interaction to this degree remains unique.

9 More about the 20th of February movement in Morocco, see Rahman 2012. 


\section{Justice and Spirituality}

Notwithstanding the popularity of tariqa Budshishiyya, currently the biggest Islamic organisation in Morocco is Al- 'adl wa al-Ihsan - 'Justice and Spirituality', as translated by one of respondents. Its ideology can be defined as a fusion of revolutionary socialism, Sufism and conservative Islam (Lefèvre 2013: 626-629). Some scholars also claim that it combines teachings of conservative maliki Islam and Sufi mysticism (Soage 2013). During the fieldwork, many respondents also mentioned Al- 'adl wa al-Ihsan as an important religious actor in Morocco. However, respondents' knowledge about this organisation could be defined as fragmental, since most of the time they themselves were not confident in the information provided. Most likely, this can be attributed to the ambiguous official status of the organisation, which will be discussed further below.

During the fieldwork, it proved extremely hard to contact and interview members of this organisation. Therefore, the following ideas are largely based on information gathered during an interview with a young male member of Al-'adl wa al-Ihsan from one of the popular neighbourhoods of Fez. As he explained it, Al- 'adl wa al-Ihsan is an organisation orientated towards both social and spiritual progress, tracing its legacy from tariqa Budshishiyya (some respondents even characterised Al- adl wa al-Ihsan as an "offshoot" of it). ${ }^{10}$ An important aspect that it shares with non-legalistic Islam is the charismatic leadership of its previous leader Asslam Yassine, who even took a Sufi title of sheik:

It is to achieve justice, like there is injustice, unfairness on earth, so they try to make a reform to achieve some sort of justice [...] the individual, he has to reach the highest level of spirituality and society has to reach the justice. [...] Just like when you are with them, you are comfortable, you are improving your spirituality, when you start loving God, and this is from Sufism, because the leader of Al-' adl wa al-Ihsan was a member of Sufism, like tariqa Budshishiya. (A young male member of Al-'adl wa al-Ihsan, Fez, 22 Mar. 2015)

When asked about the goals and aims of Al-'adl wa al-Ihsan, the informant drew his attention towards its syncretic nature, referring to the divorce of legalistic and non-legalistic Islam and a unifying mission of his organisation:

Islam in the era of Prophet, peace be upon him, was unified[...] afterwards, after the death of the companion Sidi Ali, Islam like, well we can say[...] disunity. Like fall apart: some people just focus just on one thing. He unified them, then all fell apart and everyone is just focused on one thing, on these fragments - everyone just on one fragment[...] the organisation tries to unify those fragments just to make it as it was at first - unified. (A young male member of Al-'adl wa al-Ihsan, Fez, 22 Mar. 2015)

Throughout the interview, respondent repeatedly highlighted two levels of Al-'adl wa al-Ihsan activities: the societal and the individual, each complementing the other. He stressed the need for members to act as role models in order to enable societal progress defined as justice. On the other hand, personal development is also important. As he puts it, it can be reached whether through spiritual rituals attributed to Sufism like $d h i k r$ 'repetition of names of God' or social work, both practised within the organisation:

Activities, they are divided into 2 groups: the first one is to reach the highest level of spirituality, so they are repeating names of God, $\operatorname{dhikr}[\ldots]$ They have meetings weekly or monthly just to achieve

10 More information in English, French, and Arabic is available at <www.en.yassine.net>. 
that goal[...] every time it is like a meeting that sports, politics, religion. They just do not focus on one thing $[. .$.$] I have a meeting tonight with, like, kids, to teach them and entertain them. (A young$ male member of Al-' adl wa al-Ihsan, Fez, 22 Mar. 2015)

Judging from research findings, the popularity of Al-'adl wa al-Ihsan can be seen in the light of its outreach towards the popular masses, social work done by its members, and its rather syncretic religious agenda. Just as in the case of Budshishiyya or neo-Sufism, it corresponds to religious demands of the wider society.

However, the relationship between the Moroccan monarchy and Al- adl wa al-Ihsan is rather tense:

If you reach that highest level of spirituality, God loves you and helps you and enables you to reach, to achieve justice on earth, so the principle is to reach Ihsan, the highest level of spirituality, the fundamentals[...] and through that you can like go out and try to preach to the people[...] Word is through politics $[. .$.$] they are going to politics to achieve justice and tell people what are their$ duties and their rights. (A young male member of Al-'adl wa al-Ihsan, Fez, 22 Mar. 2015)

As explained above, the spiritual and social orientation of Al-'adl wa al-Ihsan results in involvement in national politics. This stands in sharp contrast with, for example, Budshishiyya, which although generally apolitical, still supports the monarchy. As put by a student of Sufi literature studies:

There are two, basically, political movements: one in zawiya Budshishiyya, one with the king and the actual regime, and the second, which is Al-'adl wa al-Ihsan, which is against the actual regime. (A male student of Sufi literature, Fez, 23 Mar. 2015)

Thus, Al-'adl wa al-Ihsan is not only a partly political organisation, it is also critical towards the monarchy. It has been so since 1974, when sheik Yassine published his satirical epistle al-Islam aw al-Tawfan ('Islam or the Deluge'), an open letter to Hassan II, in which he accused the monarch of being a tyrant and demanded social justice (Soage 2013: 4). As the respondent explains, this tension lasted until the death of the sheik in 2012. Nonetheless, for the members of the organisation it is still relevant today:

He is mistaking, he is wrong, you can say[...] he is just a label-Amir al-Mu'minin[...] every man, every citizen in Morocco believes in that. It is just a label[...] Islam does not force people to do things, it just tries to advise you, try to give you an advice, good advice.

The last king was Hassan II, and the former leader of this organisation sent him an advisory message, a letter to the former king. In which he advised him to try to[...] the answer was negative, and he put him in jail. In 2000, he sent another message to the new king, the current king which is the[...] he gives him new ideas, but unfortunately[...] there is not only the king, there is a hierarchy[...] so all the people around the king did not accept. (A young male member of Al-'adl wa al-Ihsan, Fez, 22 Mar. 2015)

Hence, reacting to the critique, the Moroccan monarchy imposed sanctions on Al-'adl wa al-Ihsan: sheik Asslam Yassine was imprisoned several times and organisation's political activity is still banned in the country. The state only tolerates Al- 'adl wa al-Ihsan as a religious community. A question - why this opposition did not provoke any larger scale conflicts - can possibly be answered by referring to the non-violent agenda of Al-'adl wa al-Ihsan, probably inherited from its parent Sufi organisation:

The organisation has three fundamentals or principles: 1) their works, they do it in public; 2) no violence; 3 ) there is no like, they have no relation with foreigners, no funds that come from other countries. (A young male member of Al-' adl wa al-Ihsan, Fez, 22 Mar. 2015) 
Summing up, we should note that Al-'adl wa al-Ihsan, because of its syncretic religious agenda and incorporation of traditional Sufi rituals, can be defined as yet another expression of reformed non-legalistic Islam. Even though it criticizes the Moroccan monarchy and is constantly sanctioned, its members refrain from violent actions and concentrate on social work and outreach towards the popular masses. This fusion of sanctions and partial toleration from the side of the monarchy can be interpreted as a governance strategy towards a moderate opposition. We can even speculate that it is partly beneficial for the state: members of the wider society under the influence of Al- adl wa al-Ihsan concentrate on spiritual improvement and social work. Therefore, the critique expressed by them does not have the potential to grow into more radical acts. Thus, it may even facilitate political stability.

\section{COHABITATION OF NON-LEGALISTIC ISLAM AND THE MOROCCAN MONARCHY}

In this chapter, an analytical model, constructed according to the aforementioned fieldwork findings, is presented.

In the model (Fig. 2), dimensions of traditional and reformed non-legalistic Islam and the religious actors attributed to them are represented by areas I and II. The institution of Moroccan monarchy actively interacting with both of these areas, employing different governance tools and tactics, is accordingly placed in the middle. Arrows linking different actors represent the second dimension, top-down and bottom-up incentives for establishing this cohabitation. In biology, the term cohabitation broadly defines the act of different species living together in the same habitat, whereas, as this paper argues, it can also cover a special relationship between the state and non-legalistic Islam.

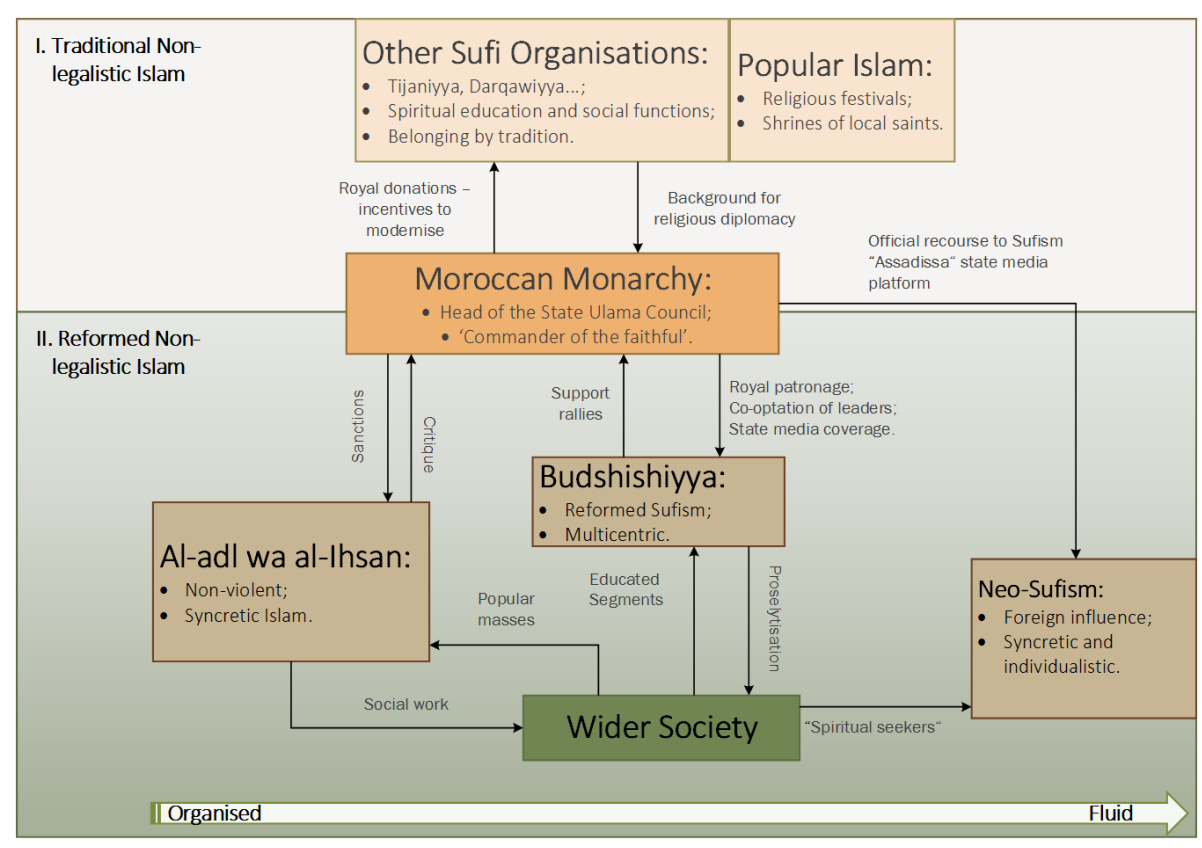

Figure 2 Cohabitation of non-legalistic Islam and the Moroccan monarchy 
Segmentary theory, as put forward by Ernest Gellner, can be used in trying to comprehend the interrelatedness illustrated by part I, covering interactions between the Moroccan monarchy and actors of traditional non-legalistic Islam. As discussed previously, these dynamics take different forms. For example, the palace partly funds traditional Sufi organisations and popular Islam, and the king frequently visits different zawiya. On the other side, traditional turuq are known within society for providing certain educational and social functions in the Moroccan periphery. Thus, royal funding received by these actors may not only motivate their religious and social modernisation, but indirectly help to provide those societal services, as well. Moreover, a recent tendency noted while conducting the fieldwork is the use of transnational Sufi networks for establishing the king of Morocco as a regional leader. Even though this tendency is a complex international issue, in this model it is acknowledged for its importance at the domestic level, highlighted by the participants of the fieldwork themselves. Nevertheless, segmentary theory and these dynamics do not suffice to explain political stability in Morocco, since, at least among the participants of this study, it is generally agreed that traditional Sufi organisations are not willing or do not have the capacity to attract new followers and sustain politically relevant organisational structures. Besides that, Gellner's model is not able to accommodate the role of new actors representing non-legalistic Islam in present-day Morocco.

Thus, a theory complemented by "Governance of Religion" approach is employed. It allows for identifying and focusing on three more actors representing reformed non-legalistic Islam. All of them differ in terms of their organisational integration and stance towards the central government: fluid neo-Sufism, a reformed traditional Sufi organisation Budshishiyya, and its offshoot organisation Al- 'adl wa al-Ihsan. Although all of them interpret tradition of Moroccan non-legalistic Islam individually, their abilities to attract new segments from the wider society make them relevant not only religiously, but politically, as well. In other words, the actors represented in part II are able to involve members of the wider society in the pacifying influence of non-legalistic Islam and add to the facilitation of regime survival and political stability in Morocco. Accordingly, the state employs different governance strategies to interact with these actors ranging from regulation, self-regulation to co-regulation.

In other words, the religiopolitical processes taking place in contemporary Morocco cannot be understood only by analysing interactions and arbitrations between Sufi sheiks, the monarchy and the society (as proposed by segmentary theory). Instead, we should focus on multidirectional interactions between the state and religious actors produced by the recent shifts in Islam and religion, in general. Moreover, we have to highlight not only top-down cooperation initiatives, but also the organisational capacities of religious actors themselves, which in some cases even have some advantage vis-à-vis the state. Accordingly, the model, presented by the Figure 2, proposes a framework, which is hopefully useful in trying to "map" and grasp the complicated relationship between non-legalistic Islam and the Moroccan monarchy, which, as suggested by the findings of the study, recently re-emerged as a politically relevant factor.

\section{CONCLUSION}

This paper has dealt with a theoretical problem highlighted by Moroccan distinctness, defined by the comparably stable political situation in the country. Taking into account the important position of Islam in public sphere of Muslim societies, non-legalistic Islam, because of its presumed capacity to facilitate political stability, has been chosen as the focus point of this study. 
The analysis of data gathered during the fieldwork suggests that it may be useful to see the interactions between the Moroccan monarchy, Sufi brotherhoods, and other actors of nonlegalistic Islam as a "field" in terms of Pierre Bourdieu, that is a "relatively autonomous social space constituted around a specific social activity and, more specifically, around the conflictual relations between actors who practice this activity" (Louër 2008: 1). Drawing on this idea, the article attempts to characterize identified religious actors and to place them in the "field", which, as it is hypothesized, is important for the facilitation of political stability in the country.

By defining different incentives for cooperation and conflict between the monarchy and actors of non-legalistic Islam, the constructed analytical model aims to sketch the rough lines of what may be called a cohabitation between the two, and to present the range of their interactions. In other words, the article elaborates on ideas put forward by Mausen and Bader and presents one of the possible interpretations of how "governance" of non-legalistic Islam takes place in Morocco. As has been shown, the monarchy indeed applies various governance tools while regulating or co-regulating this "field", including direct funding, co-optation of religious leaders, sanctions, and other governance tools that up to certain degree are mutually beneficial for both sides. As argued by the vast majority of respondents, this alone adds to the political stability of the country.

Nonetheless, several limitations need to be mentioned here. First and foremost, the research design employed by this study is not suitable for making far-reaching generalisations. The analytical model presented in the last section of the article is based on information gathered from a comparatively small group of respondents (35). Additionally, it should be noted that the use of snowball sampling may have increased the risk of the research referring to the same closed group of people, who may be similar in terms of personal bias, exaggeration, selective memory, and so forth. Moreover, it is important to mention that some of the interviews were carried out with the help of interpreters or using languages that were not native tongues of respondents. Although much effort was put into accuracy of translation, there is always a risk of misinterpretation. Finally, the personal biases and limitations of the author are also relevant, since throughout the research, as a non-Muslim, he was not allowed to enter mosques and other places considered to be of high religious importance. In this case, he had to rely on the help of assistants, because they were able to go inside and find people who would be willing to have interviews outside or close to mosques, zawiyas, and so on.

Taking all of this into account, one should not discount the fact that the chosen research design allowed the construction of a conceptually dense analytical model that may serve as a basis for further academic elaboration. For example, further research may take a more in-depth look at how inner organisational reforms of religious groups impact their capacities to engage in political action or participate in the delivery of social services in the Moroccan periphery and urban areas, or how international networks of non-legalistic Islam may be mobilized for establishing the domestic and international political authority of the Moroccan monarchy. For dealing with these questions, not only local community leaders, but people with higher ranking in political and religious hierarchies should be interviewed, as well. In addition, a longitudinal approach may be employed while dealing with the sustainability of the "field" defined by this article. The course of international politics and globalisation are just a few of the factors that may influence the continuities and ruptures that we will probably witness in the cohabitation of non-legalistic Islam and the Moroccan monarchy. 


\section{REFERENCES}

Arifianto, Alexander 2012. Faith, Moral Authority, and Politics: The Making of "progressive Islam" in Indonesia and Turkey. Paper presented at the Annual meeting of the Western Political Science Association, Portland.

Barton, Greg 2005. Progressive Islamic Thought, Civil Society, and the Gulen Movement in the National Context: Parallels with Indonesia. Paper presented at the Fethullah Gulen Conference, Houston.

Bekkaoui, Khalid \& Ricardo René Larémont 2011. Moroccan Youth Go Sufi. The Journal of the Middle East and Africa 1(2): 31-46.

Berque, Jacques 1982. Ulémas, fondateurs, insurgés du Maghreb: XVII siècle. Paris: Sinbad.

Browers, Michaelle \& Charles Kurzman (eds) 2004. An Islamic Reformation? NY: Lexington Books.

Bryman, Alan 2008. Social Research Methods. Oxford: OUP.

CALDER, Norman 2016. Law: Legal thought and jurisprudence. In: The Oxford Encyclopedia of the Islamic World. Oxford Islamic Studies Online, <www.oxfordislamicstudies.com/article/opr/t236/e0473>, accessed 2 Nov. 2016.

Снін, Rachida 2012. Sufism, Education and Politics in Contemporary Morocco. Journal for Islamic Studies 32(1): 24-46.

CHiтtick, William C. 2016. Sufism: Sufi thought and practice. In: The Oxford Encyclopedia of the Islamic World. Oxford Islamic Studies Online, <www.oxfordislamicstudies.com/article/opr/t236/e0759>, accessed 1 Nov. 2016.

Combs-Schilling, Elaine 1989. Sacred Performances: Islam, sexuality and sacrifice. NY: Columbia University Press.

Denoeux, Guilian 2002. The Forgotten Swamp. Middle East Policy 9(2): 58-69.

Dominguez-Diaz, Marta 2011. Shifting Fieldsites: An Alternative approach to fieldwork in transnational Sufism. Fieldwork in Religion 6(1): 1-15.

Dominguez-Diaz, Marta 2015. Women in Sufism: Female religiosities in a transnational order. NY: Routledge.

Eickelman, Dale F. 2016. Popular Religion: Popular religion in the Middle East and North Africa. In: The Oxford Encyclopedia of the Islamic World. Oxford Islamic Studies Online, <www.oxfordislamicstudies.com/ article/opr/t236/e0642>, accessed 30 Oct. 2016.

Esposito, John L. 2016. Islamic Revivalism or "Fundamentalism". In: The Oxford Encyclopedia of the Islamic World. Oxford Islamic Studies Online, <www.oxfordislamicstudies.com/article/opr/t236/e0383>, accessed 30 Oct. 2016.

GeERTz, Clifford 1971. Islam Observed: Religious development in Morocco and Indonesia. Chicago: UCP.

Gellner, Ernest 1969. Saints of the Atlas. London: Weidenfeld \& Nicolson.

Gellner, Ernest 1992. Postmodernizmas, protas ir religija. Vilnius: Pradai.

Ghoulaichi, Fatima 2005. Of Saints and Sharifian Kings in Morocco: Three examples of the politics of reimagining history through reinventing king/saint relationship. Maryland: University of Maryland.

Haenni, Patrick \& Raphael Voix 2007. God by All Mean: Eclectic faith and Sufi resurgence among the Moroccan bourgeoisie. In: M. van BRuinessen \& J.D. Howell (eds), Sufism and the "Modern” in Islam: 241-257. London: I.B. Tauris.

Hassan, Riaz 2015. Power and Piety: Religion, State and Society in Muslim Countries. Paper presented at the Annual International Conference on Islamic Studies, Manado.

Julien, Charles-André 1978. Le Maroc face aux impérialismes: 1415-1956. Paris: Éditions du Jaguar.

Julien, Charles-André 1982. L'Afrique du Nord en marche. Paris: Omnibus.

LAhouari, Addi 2009. Islam Re-Observed: Sanctity, Salafism and Islamism. The Journal of North African Studies 14(3): 331-345.

Lefèvre, Raphael 2013. Balancing Act: Islamism and the monarchy in Morocco. The Journal of North African Studies 18(4): 626-629.

Lofland, John \& Norman Skonovd 1981. Conversion Motifs. Journal for the Scientific Study of Religion 20(4): 373-385.

LouËr, Laurence 2008. Transnational Shia Politics: Religious and political networks in the Gulf. NY: Columbia University Press.

Marabout. In: J.L. Esposito (ed.), The Oxford Dictionary of Islam. Oxford Islamic Studies Online. <www.oxfordislamicstudies.com/article/opr/t125/e1431>, accessed 21 Apr. 2017. 
Mausen, Marcel, Veit Bader \& Annellies Moors (eds) 2011. Colonial and Post-Colonial Governance of Islam: Continuities and ruptures. Amsterdam: Amsterdam University Press.

Migdal, Joel 2004. State in Society: Studying how states and societies transform and constitute one another. Cambridge: CUP.

Morris, Brian 2006. Religion and Anthropology: A Critical introduction. Cambridge: CUP.

MuEdini, Fait 2015. Sponsoring Sufism: How governments promote 'mystical Islam' in domestic and foreign policies. NY: Palgrave Macmillan.

Munson, Henry 1993. Religion and Power in Morocco. Chelsea: YUP.

PARgeter, Allison 2009. Localism and Radicalization in North Africa: Local factors and the development of political Islam in Morocco, Tunisia, and Libya. International Affairs 85(5): 1031-1044.

RAČIUS, Egdūnas 1997. Postmodernus modernybès atsakas. Sociologija: Mintis ir veiksmas 1(1): 184-188.

RAČIUS, Egdūnas 2005. Politikos ir islamiškosios davos susiliejimas. Politologija 38(2): 91-122.

RAČIUS, Egdūnas 2013. Musulmonų visuomenès ir bendruomenès. In: International Organisation for Migration (ed), Tarpkultūrinio pažinimo vadovas dirbantiems su trečiuju šaliu piliečiu šeimomis: 18-22. Vilnius: International Organisation for Migration.

Rahman, Zahir 2012. Online Political Activism in Morocco. Journal of New Media Studies in MENA 1(1): 1-13.

SoAge, Ana Belen 2013. Political Islam in Morocco: Is there an “exception Marocaine?" Middle East Review of International Affairs 17(3): 1-8.

Strauss, Anselm \& Juliet Corbin 1994. Grounded Theory Methodology: An Overview. In: N. DenZin \& Y. LincolN (eds), Handbook of Qualitative Research: 273-285. Thousand Oaks: Sage Publications.

Swartz, David 1997. Culture and Power: The Sociology of Pierre Bourdieu. Chicago: UCP.

Tadlaoui, Ghita 2015. Morocco's Religious Diplomacy in Africa. FRIDE Policy Brief 196: 1-5.

TовоLка, Radim 2003. Gellner and Geertz in Morocco: A Segmentary debate. Social Evolution \& History 2(2): 88-117.

Waterbury, John 1970. The Commander of the Faithful: The Moroccan political elite: A Study of segmented politics. NY: Columbia University Press.

Zorin, Andrey 2001. Ideology, Semiotics, and Clifford Geertz: Some Russian reflections. History and Theory 40(1): 57-73. 